\title{
YOSHIHIDE SUGA POLICY DALAM MELANJUTKAN ABENOMICS DI KAWASAN ASIA TIMUR DAN TENGGARA
}

\author{
Ade Priangani ${ }^{1}$, Kunkunrat $^{2}$, Rangga MS. Saputra ${ }^{3}$ \\ ${ }^{1}$ Program Studi Hubungan Internasional Fakultas Ilmu Sosial dan Ilmu \\ Politik Universitas Pasundan \\ adepriangani@rocketmail.com \\ ${ }^{2}$ Program Studi Hubungan Internasional Fakultas Ilmu Sosial dan Ilmu \\ Politik Universitas Pasundan \\ ${ }^{3}$ Program Studi Hubungan Internasional Fakultas Ilmu Sosial dan Ilmu \\ Politik Universitas Pasundan \\ ranggarjuna2000@gmail.com
}

\begin{abstract}
This article describes a problem regarding abenomics made by Shinzo Abe as the basis of Japan's domestic political economy and foreign policy which began in 2012. However, after Shinzo Abe's emergence as PM of Japan and replaced by Yoshihide Suga, Suga continued abenomics with the aim of improving and stabilization of both Japan Domestic and Asia Pacific region, stimulaneously with RCEP which was signed in November 2020. The author takes the concept of Foreign Policy in which Japan improves its leadership strategy in balancing China's influence on the East Asian Region and ASEAN. The assumption of the leadership strategy is that the state has the capability of power but does not engage in conflictualism with other countries, so that it cooperates with a sense of competitiveness of a country. The result of the analysis shows that Japan sees an opportunity with the RCEP. Previously Japan did not focus on RCEP as part of Abenomics but rather on the CPTPP. $R C E P$ can encourage the export of Japanese products or commodities, RCEP is the most important part for Japan in the economy on free economy in Asia Pacific region. However, the challenge from Japan is that China still has a strong influence on ASEAN and RCEP has low trade liberalization. So that India left RCEP because of concerns that India's local products could not compete with other countries, especially China, with products that were cheap and accessible to the public. In addition, ASEAN sees China as no longer a threat because it sees China as a potential market for ASEAN. The impact for Indonesia is to get the maximum benefit from the Sino-Japanese competition, one of which is the joint project of the Jakarta-Bandung Fast Train as an interest of Indonesia which implements a Free Active Foreign Policy.
\end{abstract}

Keywords: Yoshihide Suga Policy; Abenomics; East Asia, South-east Asia

\section{PENDAHULUAN}

Abenomics merupakan kebijakan ekonomi yang diterapkan oleh Jepang sejak 2012. Abenomics ini dinamai dari nama pencetusnya, Shinzo 
Abe, yang menjadi Perdana Menteri Jepang dari tahun 2012 sampai 2020. Abenomics memiliki pondasi yang disebut sebagai Three Arrows yaitu: (1) Structural Reform ini lebih kepada penggunaan kas negara yang difokuskan kepada Infrastruktur, dan Insentif pajak mengacu pada upaya yang dilakukan untuk menarik investor dalam mendorong aktivitas perekonomian, (2) Monetary Policy yang dikeluarkan oleh bank sentral untuk mengatur persediaan uang dimana Jepang pada saat ini ingin menurunkan nilai sehingga menyentuh angka $2 \%$, dan mendongkrak perekonomian internal, dikarenakan kondisi Jepang yang dikatakan krusial untuk mengurangi defisit dengan cara menaikan pajak pendapatan dari 5\% menjadi 8\%. (3) Stimulus fiskal / konsolidasi fiskal poin ke-3 ini merupakan masalah yang sangat banyak dimana menurut Organisasi Kerjasama Pembangunan Ekonomi (OECD) Jepang memiliki GDP paling tinggi diantara negara lainya namun perekonomian Jepang masih statis (Aramaki, 2019; The Government of Japan, 2017) .

Three Arrows dalam Abenomics ini adalah langkah-langkah dan kebijakan pemerintah Jepang yang berpengaruh besar bagi perekonomian Jepang dari tahun 2012 sampai tahun 2020, dan berhasil memacu pertumbuhan ekonomi Jepang serta melahirkan metode baru untuk pembiayaan bisnis lokal dan usaha kecil menengah (UKM).

Kondisi Jepang sebelum adanya Abenomics, memiliki masalah yang disebabkan karena banyaknya populasi penuaan (kurangnya angka kelahiran), kurangnya efisiensi dan efektifitas investasi publik, dan pertumbuhan ekonomi Jepang yang dapat dikatakan lesu. Untuk mengatasi permasalahan ini Perdana Menteri Shinzo Abe mengenalkan program reformasi ekonomi yang disebut Abenomics dan bertujuan untuk menghidupkan perekonomian Jepang dengan 3 pondasi pentingnya yang disebut sebagai Three Arrows yaitu reformasi struktural, reformasi kebijakan moneter, dan stimulus fiskal atau konsolidasi fiskal yang mampu memberikan hasil terhadap perekonomian Jepang hingga saat ini (Aramaki, 2019).

Setelah Shinzo Abe mengundurkan diri sebagai PM Jepang, kebijakan ini diteruskan oleh Yoshihide Suga yang bermimpi untuk 
melanjutkan stimulus ekonomi Abenomics. Suga yang berlatar belakang keluarga petani, sukses sebagai politisi Partai Liberal Democratic Party (LDP) dan sekaligus sebagai tangan kanan PM Abe. Berkaitan dengan upaya melanjutkan Abenomics, Suga telah melakukan kunjungan ke negara-negara tetangga di Asia Timur seperti Korea Selatan dan Asia Tenggara diantaranya Indonesia.

Kunjungan Suga ke Korea Selatan membahas masalah pengadaan vaksin dan harmonisasi antara Korea Selatan-Jepang sebagaimana Kebijakan Luar Negeri Jepang yang mengedepankan nilai pasifis-revisionis (Kan, 2020; Rezkisari, 2020). Kepentingan Jepang terhadap Kawasan perdagangan bebas terbesar di Dunia yang telah disahkan pada bulan November 2020, yaitu Regional Comprehensive Economic Partnership (RCEP). RCEP ini menjadi salah satu peluang bagi kepentingan perdagangan bebas negara-negara kawasan Asia-Pasifik meskipun India keluar dari RCEP karena belum siap untuk bersaing dalam pasar bebas ditambah lagi dari kekhawatiran dari India bahwa RCEP adalah pemanfaatan peluang dari China dalam produk ekspornya yang murah sehingga akan mengancam pada produk lokal India (Kawashima, 2020).

RCEP ini adalah atas dasar inisiasi Indonesia untuk menyempurnakan konsep perjanjian perdagangan bebas ASEAN+1 Free Trade Agreements yang anggotanya antara lain Republik Rakyat China (RRC), Jepang, Korea Selatan, Australia, dan Selandia baru. RCEP yang pertama kali diinisiasi pada KTT ASEAN ke-19 di Bali pada tahun 2011 (Ditjen Perundingan Perdagangan Internasional \& ASEAN, 2019). Selanjutnya pada November 2020, RCEP resmi ditandatangani oleh negara-negara anggota, salah satunya Jepang. Jepang berasumsi RCEP menjadi peluang dalam meningkatkan ekonomi politik Jepang, meskipun ada kekhawatiran terhadap hegemonitas China dalam geoekonomi sekaligus geostrategic China yaitu Belt And Road Initiative terutama dalam maksimilasasi militer China sejak tahun 2015. Namun ambivalensi Jepang tersebut memberikan peluang untuk mendorong pengaruh abenomics terhadap China dan juga negara-negara ASEAN salah satunya Indonesia (Fischetti \& Roth, 2019). 


\section{KERANGKA KONSEPTUAL}

Kerangka konseptual yang dipakai dalam kajian ini adalah paradigma neo-realisme dengan konsepnya yaitu Politik Luar Negeri. Kajian ini menitikberatkan pada variabel Jepang sebagai unit analisis, dalam hal ini adalah bagaimana Jepang melakukan strategi aliansi dengan kawasan Asia TImur dan ASEAN khususnya Indonesia melalui sifat pasifis revisionis yang dilanjutkan oleh Suga dari Shinzo Abe dengan tetap tidak berkonflik dengan China. Sehingga strateginya dibentuk oleh dasar model concordance strategy.

Perkembangan dari paradigma realisme menjadi transformasi pada tahun 1970-an hingga 1980-an yaitu muncul realism struktural atau disebut dengan neo-realisme. Neo-realisme adalah salah satu konsep yang dikembangkan oleh Kenneth Waltz atas dasar kritik dari realism klasik ala Morgenthau. Kenneth Waltz mengkritik dari kekurangan realisme klasik dan disempurnakan oleh John Mearsheimer. Asumsi dasar kritikannya antara lain adalah : Pertama, negara bukan hanya dipengaruhi dari human nature sebagaimana sifat realism klasik dalam teori organisme tumbuhan bahwa negara mendorong terjadinya hegemoni dan perluasan power dan sphere of influence nya untuk menjadi kekuatan dunia adalah tidak benar, justru akan menghancurkan atau menjadi boomerang sendiri bagi negara lain.

Kedua, negara harus menentukan yaitu aspek kapabilitas dan perhitungan secara rasional dalam mengidentifikasi kekuatan militer, geografi, dalam penentuan aspek cost and benefit. Sehingga aspek kapabilitas dapat diukur dengan power suatu negara. Ketiga, negara tidak bisa menjadi kekuatan global, sekalipun memang menjadikan negara great power akan menjadi ketidakstabilan dalam polaritas sistem internasional atau disebut dengan unipolar, sekalipun realism klasik mengafirmasi multipolarisme. Sehingga idealnya tatanan sistem internasional bersifat bipolar, hal ini menjadi model yang dikenal sebagai balance of power. 
Keempat, kekuatan hegemoni negara harus disesuaikan dengan model kekuatan dengan gabungan negara lain baik dalam bentuk balancing (penyeimbang), bandwagoning (bergabungnya negara-negara kecil kepada negara besar), atau hedging (pemagaran). Kelima, kekuatan struktural tersebut membentuk kekuatan negara hanya sebatas pada dominasi pada kekuatan regional, dan menginfiltrasi pada bipolarisme dengan demikian sistem internasional akan stabil (Art \& Jervis, 2017; Dunne, Kurki, \& Smith, 2010).

Sedangkan konsep Polugri adalah usaha tindakan atau aksi yang dilakukan oleh negara untuk melakukan interaksi pada sistem internasional untuk mencapai kepentingan nasional. Menurut Rosenau, Politik Luar negeri disebut sebagai kebijakan luar negeri yang merupakan upaya suatu negara melalui keseluruhan sikap dan aktivitas-aktivitasnya untuk mengatasi dan memperoleh keuntungan dari lingkungan eksternalnya (Banyu Perwita \& Yani, 2014).

Akan tetapi, sebenarnya polugri dan kebijakan luar negeri memiliki pengertian atau pembatasan yang berbeda, bedanya adalah Politik Luar Negeri lebih pada prinsip atau orientasi dari para pembuat keputusan dari suatu negara antara lain : Suprastruktur politik dan infrastruktur politik, sedangkan pada kebijakan luar negeri adalah hasil dari orientasi kebijakan yang dilakukan oleh pembuat keputusan dari negara seperti kebijakan kerjasama ekonomi, militer atau perang (Setiawan \& Sulastri, 2017).

Dengan demikian, Polugri merupakan teori aksi yang dilakukan oleh negara dalam melakukan interaksi pada sistem internasional yang artinya, Polugri merupakan salah satu perpanjangan tangan dari Politik Dalam Negeri suatu negara karena polugri berfungsi sebagai acuan dalam mempertahankan kepentingan nasional.

Polugri memiliki model-model yang diterapkan dalam menganalisis kasus interaksi negara di dalam sistem internasional. Salah satunya penulis mengambil model strategi rasional. Model strategi rasional adalah salah satu model yang dilakukan oleh suatu negara dalam melihat aspek rasionalitas suatu negara dalam melakukan interaksi dalam sistem internasional dengan mempetimbangkan aspek cost and benefit. John $\mathrm{P}$ 
Lovel mengatakan bahwa ada beberapa faktor yang mempengaruhi dalam perumusan strategi kebijakan Luar Negeri pada sistem internasional, persepsi elit, strategi negara bangsa lain dan kapabilitas yang dimiliki oleh negara tersebut. Empat faktor dalam interaksi negara antara lain adalah Leadership strategy, confrontation Strategy, dan concordance strategy (Banyu Perwita \& Yani, 2014). Akan tetapi penulis hanya mengambil model Leadership strategy berdasarkan tema yang dianalisis. Model leadership strategy adalah melihat bahwa negara yang memiliki kapabilitas power digunakan tanpa menekan negara lain yang berujung pada konfliktualisme negara, artinya negara tersebut tidak ingin memiliki kapabilitas power dengan cara hardpower melainkan menitikberatkan pada cara-cara softpower melalui cara persuasi. Sehingga tipe strategi ini lebih kepada posisi kapabilitas negara yang sudah mumpuni atau superior, sehingga negara lain mendukung dan mengikuti kebijakan negara tersebut (Banyu Perwita \& Yani, 2014; Setiawan \& Sulastri, 2017).

Dari landasan teoritis diatas dikaitkan dengan masalah yang diangkat dalam tulisan ini, maka dapat diasumsikan : satu, upaya Kebijakan Luar Negeri Jepang dalam abenomics yang dilanjutkan Suga adalah leadership strategy yang dilakukan oleh Jepang sebagai negara dominan di kawasan Asia Timur dan berperan penting dalam ASEAN; dua, upaya tersebut dilakukan dengan upaya neo-realisme Jepang dalam memyeimbangkan pengaruh China yang dikenal dengan BRI, sehingga mendorong terjadinya upaya strategi peluang dalam kompetisi melalui kerjasama ekonomi bersamaan dengan adanya RCEP; tiga, RCEP yang diinisiasi oleh Indonesia sebagai negara anggota ASEAN ini menjadi salah satu peluang dalam upaya meningkatkan ekonomi dalam kepentingan nasional Jepang dan pengaruh dari Abenomics kepada China dan juga ASEAN khususnya Indonesia.

\section{PEMBAHASAN}

Pada masa sebelumnya Jepang mengalami masa stagnasi, dimulai dengan tiga angka terpenting dalam ekonomi, PDB riil (nyata) tingkat pertumbuhan, tingkat pengangguran, dan tingkat inflasi. Sebelum tahun 
1990, Jepang mencapai pertumbuhan rata-rata 4 persen, tetapi tingkat pertumbuhan menurun menjadi kurang dari 2 persen selama tahun 1990-an dan bahkan kurang dari itu pada dekade pertama tahun 2000-an.

Periode pertama pemerintahan Shinzo Abe dimulai dengan harapan besar. Dia antusias untuk mereformasi Jepang kerangka konstitusional pasca-Perang Dunia dan sistem administrasi publik. Rencana ekonomi awalnya adalah cukup ambisius untuk mencapai tingkat pertumbuhan PDB nya. Pada bagian ini, kita akan melihat manajemen kebijakan moneter yang diperkenalkan oleh Gubernur Kuroda pada April 2013 sebagai panah pertama Abenomics dengan membagi periode menjadi dua, yaitu periode hingga penerapan kebijakan suku bunga nol (1991-1999) (pada dasarnya periode sebelum ekonomi mengalami deflasi dan ditempatkan di bawah batasan nol batas bawah pada tingkat bunga) dan periode setelah itu (periode setelah ekonomi ditempatkan di bawah deflasi dan batasan batas bawah nol) (Wakatabe, 2015).

Kebijakan ekonomi Abe juga terkait dengan kebangkitan China sebagai kekuatan ekonomi dan politik. Pendukung Abe menarik kesejajaran eksplisit antara Abenomics dan program era Meiji dari kukoku kyohei (memperkaya negara, memperkuat tentara) (Aramaki, 2018). Selain memberikan penyeimbang yang lebih kuat kepada China di kawasan Asia Pasifik, penguatan ekonomi Jepang juga dimaksudkan agar Jepang tidak terlalu bergantung pada Amerika Serikat untuk pertahanan (Dourille-Feer, 2015; Wakatabe, 2015).

Pada saat Jepang mengalami Security Dilemma yang luar biasa, disisi lain pertumbuhan China sangat pesat, hal ini memaksa Jepang berada dalam keadaan terpuruk dan disisi lain Jepang juga tidak dapat meminta bantuan terus menerus kepada Amerika, karena pasca Perang Dingin secara perlahan AS mengurangi kehadirannya di Asia Pasifik dengan cara mengedepankan sekutu-sekutunya dan membangun konstruksi keseimbangan strategis yang dilandaskan pada keberadaan sekutu-sekutunya di kawasan. Penyesuaian postur kehadiran militer AS di Asia Pasifik, pada hakikatnya dilandasi oleh penilaian bahwa situasi 
keamanan di kawasan relatif tidak mengancam kepentingan-kepentingan AS. (Sari \& Yani, 2017)

Jepang memandang China telah meningkatkan keberadaannya dalam komunitas internasional termasuk ke dalam global ekonomi telah menjadi ancaman yang nyata, mengingat China berencana untuk mempromosikan reformasi militer hingga 2020, Jepang memandang perlunya memprioritaskan untuk membangun kekuatan militer. China diperkirakan akan terus meningkatkan kekuatan nuklir dan misilnya. Hal kedua dalam security dilemma Jepang adalah hubungannya dengan Amerika, dimana Amerika sedang dalam kondisi yang panas dengan China, seperti masalah perdagangan (Aramaki, 2019).

Keberhasilan atau kegagalan Abenomics, dan Jepang secara umum, sangat penting bagi seluruh dunia, khususnya Asia Tenggara. Meskipun 15 tahun pertumbuhannya rendah, Jepang tetap adalah negara dengan ekonomi terbesar ketiga dan kreditor terbersih, serta negara dengan total perdagangan terbesar. Abenomics dapat mempengaruhi negara lain dalam berbagai variasi cara. Pelemahan yen akan cenderung membebani negara yang menjadi pesaing langsung, seperti Korea.

Penyeimbangan kembali portofolio oleh lembaga keuangan dan rumah tangga Jepang akan menghasilkan arus keluar modal, termasuk ke negara berkembang Asia. Sejauh ini, limpahan seperti itu telah diatasi, dengan arus keluar bersih terbatas dan ekspor Jepang belum meningkat secara menentukan. Tetapi jika Abenomics ingin berhasil, kemungkinan besar akan menghasilkan limpahan yang lebih besar di sepanjang garis yang dijelaskan di atas. Meskipun saluran individu ini penting, poin utamanya adalah bahwa dinamis dan bertumbuh Jepang tidak diragukan lagi akan menjadi anugerah bagi tetangganya, dan ekonomi global (Aramaki, 2019; Dourille-Feer, 2015; Wakatabe, 2015).

Aspek terpenting dari Abenomics adalah kontribusinya untuk penyeimbangan kembali di Asia Timur. Salah satu masalah utama yang sangat bergantung pada perdagangan adalah bahwa ekonomi Asia Timur rentan terhadap negara-negara OECD bahkan ASEAN. Kebijaksanaan konvensional Jepang dalam penyeimbangan kembali negara menyiratkan 
lebih sedikit ketergantungan pada ekspor. Namun, rebalancing memiliki arti yang berbeda untuk negara yang berbeda. Untuk negara-negara seperti Malaysia dan Singapura, penyeimbangan kembali pasti akan mengurangi ketergantungan pada perdagangan. Dalam kasus Cina, penyeimbangan ulang akan berarti pertumbuhan yang lebih didorong oleh konsumsi dan tingkat investasi yang lebih rendah, dan kebalikannya untuk Filipina (Tay, 2013; Yoshino \& Taghizadeh-Hesary, 2014).

Dengan jumlah penduduk yang besar, Indonesia dapat lebih mengandalkan pasar domestiknya untuk pertumbuhan ekonomi. Masalah utamanya adalah bahwa negara-negara ASEAN harus menerapkan langkah-langkah kebijakan untuk mencapai penyeimbangan. Negara-negara Asia Timur juga dapat menyesuaikan rebalancing di tingkat domestik dengan rebalancing di tingkat regional. Yang terakhir ini berarti lebih sedikit ketergantungan pada negara-negara industri di Barat sebagai pasar ekspor mereka. Sektor pertanian yang kurang terlindungi di Jepang akan membuka peluang ekspor bagi negara-negara dengan sektor pertanian dengan produktivitas tinggi. Negara-negara ASEAN akan mendapatkan keuntungan dari impor makanan Jepang yang lebih tinggi. Harga pangan yang lebih rendah dinegaranya akan bernilai lebih tinggi bila dilempar ke pasar Jepang. Perdagangan intra-regional di Asia Timur diseimbangkan dengan cara negara-negara ASEAN memenuhi kebutuhan barang konsumsi dari Jepang maupun China (Tay, 2013; Yap, 2013).

Dalam menyikapi Abenomics, ada pandangan yang berbeda antara negara-negara Asia Timur Laut dengan negara-negara ASEAN. Negara-negara Asia Timur Laut bersikap skeptis dan memandang negatif, sedangkan ASEAN, sebaliknya, sebagian besar positif.

Dalam kaitan sikap negara-negara Asia Timur Laut, seperti contohnya China, berpandangan bahwa Abenomics akan gagal, dan bahkan Korea Selatan khawatir bahwa Abenomics terlalu agresif dalam menurunkan nilai yen, sehingga membuat harga produk Jepang lebih kompetitif sehingga nantinya akan terjadi persaingan langsung antar perusahaan dari kedua negara. Ekspor menyumbang sekitar setengah dari PDB Korea Selatan dengan Jepang dan Korea Selatan mengekspor produk 
serupa ke pasar serupa, dari elektronik hingga mobil dan pembuatan kapal. Depresiasi yen tergantung pada perhitungan antara 16 persen dan 25 persen selama enam bulan terhadap dolar AS telah menimbulkan tantangan besar bagi Korea Selatan, yang won telah terdepresiasi hanya 2,7 persen pada periode yang sama.

Sementara ASEAN bereaksi positif terhadap Abenomics, bahkan berharap akan mendapatkan keuntungan dari kebangkitan Jepang. Jepang telah dan tetap menjadi mitra penting dan pemain ekonomi utama di kawasan, yang selama beberapa tahun ke belakang ketika Jepang mengalami kemandegan ekonomi, celah tersebut sempat digantikan China, terutama dalam perdagangan. Pada tahun 2000, total perdagangan dua arah ASEAN-Jepang adalah US\$ 128,1 miliar, sedangkan perdagangan ASEAN-China hanya mencapai US\$ 38,5 miliar kurang dari sepertiga dari ukurannya. Dekade berikutnya sampai 2011, perdagangan ASEAN-Jepang adalah US\$ 273,3 miliar, namun posisinya disalip oleh perdagangan ASEAN-Cina yang mencapai US\$ 280,4 miliar (angka Sekretariat ASEAN dan Pusat ASEAN-Jepang). Sementara dalam investasi, Jepang tetap unggul, dan tetap menjadi sumber investasi eksternal terbesar kedua ke ASEAN dengan aliran masuk FDI US\$ 15,0 miliar, sementara China berada di urutan ketiga dengan US\$ 6,0 miliar (Tay, 2013; Yap, 2013).

Angka perdagangan dan investasi ini menggarisbawahi perbedaan mendasar dalam hubungan ekonomi antara dua raksasa Asia itu dengan ASEAN. Perdagangan China, terutama dalam sumber daya, telah berkembang pesat tetapi banyak perusahaannya bersaing dengan perusahaan ASEAN. Sebaliknya, meskipun permintaan perdagangan dari Jepang belum tumbuh, ekonominya yang lebih maju melengkapi ASEAN, dan perusahaan multinasional Jepang telah lama mempertimbangkan untuk berinvestasi di Asia Tenggara sebagai basis produksi. Oleh karena itu, keberhasilan Abenomics dalam merevitalisasi ekonomi Jepang, sangat penting bagi ASEAN. Bahkan saat ini, Jepang secara khusus mulai meningkatkan investasi di industri Myanmar, Indonesia, dan Vietnam sebagai bagian dari kebijakan pemerintah Abe (Tay, 2013). 
Jepang telah mencapai hasil yang relatif terbatas dalam pembangunan kerangka kerja sama ekonomi. Perjanjian Perdagangan Bebas China-Jepang-Korea Selatan dan Perjanjian Kemitraan Ekonomi Komprehensif Regional (RCEP) telah ditunda. Khusus perjanjian RCEP, Jepang selalu berusaha menarik India ke dalam "kemitraan" untuk menahan China, yang tidak kondusif bagi perkembangan stabil hubungan ekonomi dan perdagangan China-Jepang. Suga juga melakukan tindakan penyeimbangan antara membatasi penyebaran virus corona dan menjaga perekonomian tetap berjalan.

Suga telah berjanji untuk mengikuti kebijakan Abe sambil membuat pencapaian baru, menangani hubungan Jepang dengan China. Itu berarti dia akan mencoba untuk lebih meningkatkan hubungan dengan China tetapi pada saat yang sama mengambil sikap keras terhadap China dalam kebijakan pertahanan dan keamanan, terutama mengenai Kepulauan Diaoyu (Adi Kristianto, 2020; Tan, 2020).

Disamping itu, Suga berharap hubungan Tokyo-Washington akan menjadi poros hubungan luar negeri Jepang, dengan demikian Jepang akan menjaga keseimbangan antara hubungannya dengan China dan Amerika Serikat. Dengan kata lain, Jepang akan terus sejalan dengan AS sejauh menyangkut hubungan internasional dan urusan keamanan, dan terus mendukung kebijakan AS yang menahan China, terutama di laut China Timur dan Selatan serta mengambil bagian dalam Indo-Pasifik. Di bawah prasyarat inilah Jepang akan mencari kerja sama dengan China. Menurut data yang dirilis oleh Biro Statistik Nasional Tiongkok, investasi yang dilakukan oleh Tiongkok ke Jepang setiap tahunnya mengalami tren peningkatan walaupun juga dalam beberapa tahun mengalami penurunan. (Triantama, 2020)

Jika Suga berhasil menstabilkan ekonomi dan politik Jepang, serta menahan virus corona, seperti yang telah ia janjikan, ia mungkin dapat menciptakan era pembangunan yang berbeda di Jepang, dan keluar dari bayang-bayang Abe (Adi Kristianto, 2020; Tan, 2020).

Pasca mundurnya Abe, Suga sudah menegaskan akan mempertahankan prinsip Abenomics bersama dengan kebijakan 
suplementer yaitu Suganomics dalam kebijakan ekonomi dan melanjutkan langkah-langkah penindakan COVID-19.

Sepanjang kariernya, Suga lebih banyak terlibat dalam penataan kebijakan dalam negeri, namun tentu saja tidak terlepas dari ikutan luar negeri, seperti nampak dari janjinya buat melindungi ikatan yang kokoh dengan negara-negara Asia, menguatkan pondasi aliansi Jepang- Amerika Serikat, serta melawan Cina apabila dibutuhkan (Nagata, 2020; Ratnasari, 2020).

Dalam konteks meningkatnya kekuatan dan sikap asertif China, Indonesia berada dalam posisi untuk menawarkan peluang strategis kepada Jepang. misalnya, menyusul aktivitas kapal penjaga pantai China yang tegas di sekitar Kepulauan Natuna, Indonesia meminta Jepang untuk berinvestasi di pulau-pulau yang berdekatan dengan perairan sengketa di Laut China Selatan. Indonesia berharap industri Jepang bergabung dalam konsorsium yang membangun rel kereta kilat Jakarta-Bandung, menggantikan posisi Cina dalam proyek tersebut. Interaksi baru-baru ini menampilkan Indonesia "menggunakan" keterlibatannya dengan Jepang buat menampilkan ketidaksetujuannya terhadap Cina (Noor Hidayat, 2020).

Maka dari itu kepentingan Jepang bersama-sama dengan Australia dalam strategi hedging terhadap dominasi China pada RCEP yang artinya kerjasama disertai dengan rasa kompetisi. Jepang terus berupaya mendorong kerjasama yang serupa dengan pola kerjasama negara-negara ASEAN, baik dalam kebijakan bilateralisme seperti Indonesia-Japan Economic Partnership Agreement (IJEPA) maupun dalam tataran multilateralisme Jepang-ASEAN.

Hubungan bilateral RI-Jepang, merupakan hubungan yang istimewa, karena Indonesia bagi Jepang merupakan negara bersaudara sebagaimana yang dicantumkan pada doktrin Fukuda pada tahun 1970-an, dimana Indonesia menjadi salah satu negara produksi otomotif Jepang. Hal ini akan dapat menyeimbangkan atau balance of power dibawah prinsip leadership strategy pada kebijakan Luar Negeri Jepang oleh Suga (Tani \& Gakuto, 2020; Wibowo, 2020). 
Kedudukan kunci Indonesia dalam meningkatkan kerjasama Indo-Pasifik dengan ASEAN (AOIP) meyakinkan perspektif bersama Indonesia serta Jepang di kawasan bagaikan unit strategis yang silih berhubungan, apalagi dikala kesulitan membangun ikatan yang lebih kuat dengan Cina ataupun AS. (Djegadut, 2020; Ratnasari, 2020).

Perdagangan bebas RCEP memberi peluang bagi Jepang untuk meningkatkan prestise dan kepentingan nasionalnya, karena dengan adanya RCEP, hambatan tariff akan dikurangi menjadi 86 persen dari barang industri yang diekspor Jepang ke China yang juga merupakan anggota dari RCEP (Gakuto, 2020). Hal ini tentunya akan dapat meningkatkan abenomics yang dilanjutkan oleh Yoshihide Suga dengan kekuatan ekonomi baru Jepang sebagai supllementary variables dalam memperkuat Abenomics yang telah dijalankan oleh Shinzo Abe.

Adapun hambatan bagi Yoshihide Suga dalam menjalankan Abenomics pada RCEP antara lain adalah 1) China masih dominan kuat dalam RCEP selama dekade 2010-2020, sebab Cina menempati pada posisi Ekonomi kedua, sedangkan Jepang menempati posisi ketiga, Selain itu dalam ranah ASEAN, Strategi ekonomi politik China lebih mengarah pada sektor komoditas yang dinilai menjangkau pada daya beli masyarakat dengan harga yang murah dibandingkan produk Jepang dan 2) liberalisasi perdagangan menjadikan RCEP sebagai wadah bagi China untuk memperluas pengaruh, dengan barang yang murah. Ditambah kondisi covid-19 menjadi ancaman negara lain untuk (Akbar, 2011, hal. 120; Business Insider \& Martin, 2017).

RCEP, yang pada awalnya berharap memberikan keuntungan win-win solution namun justru yang terjadi adalah barang lokal negara berkembang menjadi susah bersaing dengan China, sehingga inilah yang mendorong India keluar dari RCEP. Negara-negara ASEAN kedepannya berharap adanya harmonisasi dan yang mendongkrak nilai ekspor.

Jepang yang tidak ingin melihat kepentingan ASEAN di hegemoni oleh China, dan terutama karena Jepang juga telah melakukan perjanjian kawasan dengan doktrin Fukuda yang berisi kepentingan harmoni dan kerjasama dalam bidang industri dan pengembangan industri otomotif, 
salah satunya Indonesia, sehingga tidak ingin mengganggu perusahaan multinasional otomotif Jepang digantikan oleh China dan bahkan produk perabot rumah tangga yang mulai dibanjiri oleh China, sehingga Jepang dengan tetap mengedepankan strategi hedging memagari dominasi China namun mempertahankan kompetisi dan kerjasama. Inilah yang membuat ASEAN seperti kawasan yang diperebutkan oleh negara besar seperti dua orang cowok yang memperebutkan cewek yaitu ASEAN dan cowoknya yaitu China-Jepang.

Merujuk pada kasus Indonesia dengan kebijakan Suganomics, dan upaya Suga mengajak serta Indonesia dalam Free Open Indo-Pacific yang dikembangkan menjadi ASEAN Outlook on the Indo-Pacific dengan prinsip multilateralisme terbuka dalam kawasan Indo-pasifik dan penguatan maritim (Koga, 2016; Suoneto \& Riani, 2020). Bagi Indonesia, kebijakan luar negeri Suga dalam upaya melanggengkan Abenomics (suganomics) adalah momentum memanfaatkan kompetisi ekonomi antara China dan Jepang bagi kepentingan Indonesia. Seperti yang dikatakan Menteri Koordinator Bidang Perekonomian, Airlangga Hartanto dimana proyek kereta Cepat Jakarta-Bandung dilanjutkan ke Surabaya, dan dalam mengefisiensikan anggaran dan juga menciptakan keharmonisan antara China-Jepang (Noor Hidayat, 2020).

Dengan demikian terbukti, bahwa upaya yang dilakukan oleh Indonesia sebagai negara anggota ASEAN menginginkan agar China dan Jepang tidak terlibat perang. Strategi Abenomics yang dilanjutkan Suga, serta konsep ASEAN FOIP menjadikan kesempatan dalam pertumbuhan ekonomi bersama di Asia Timur dan Tenggara, apalagi dikuatkan dengan adanya RCEP, maka semua anggota kawasan (terutama negara-negara Asia Tenggara) akan menikmati kemajuan ekonomi, tidak terkecuali Cina dan Indonesia yang menjadi sentral kajian diatas.

\section{KESIMPULAN}

Pasca mundurnya Shinzo Abe dari PM Jepang dan digantikan oleh Yoshihide Suga, PM baru berkomitmen untuk melanjutkan Abenomics, 
sebagai salah kebijakan luar negerinya. Disamping itu, karakteristik Neo-realisme Jepang yang mewujudkan dalam konsep leadership strategy pada polugri Jepang yang mengedepankan Jepang sebagai peran utama dalam stabilisasi kerjasama berbasis kompetisi dengan China pada RCEP, meskipun memang RCEP bukan salah satu prospek yang utama bagi Jepang dan lebih mementingkan CPTPP yang dikembangkan oleh AS, namun RCEP memiliki keuntungan terutama hambatan tariff yang dikurangi menjadi 86-95 Persen. Sehingga dapat mendongkrak perekonomian Jepang dengan power ala Abenomics.

Akan tetapi pengaruh dari hegemonitas China yang masih unggul pada pasar bebas di ASEAN terutama karena harga yang lebih murah, serta industri yang efisien, telah menjadikan Cina sebagai ancaman bagi strategi Jepang di Asia Tenggara.

Indonesia dan negara-negara Asia Tenggara, memiliki keuntungan lebih dari kompetisi China-Jepang, contohnya adalah proyek kereta api cepat Jakarta-Bandung, terjadi harmonisasi antara China dan Jepang. Rencana Indonesia untuk melanjutkan sampai Surabaya, menyebabkan proyek ini bisa melibatsertakan Jepang dalam proyek sebelumnya yang hanya melibatkan konsorsium China. Sehingga proyek kereta api cepat Jakarta-Surabaya berperan sebagai balancing antara China dan Jepang.

Namun kekhawatiran bagi Jepang adalah RCEP menjadi salah satu alat bagi China untuk meningkatkan pengaruhnya di Asia Timur dan Tenggara, serta Jepang juga memandang Indonesia dan ASEAN yang cenderung terlalu dekat dengan China.

\section{DAFTAR PUSTAKA}

Adi Kristianto, Y. I. (2020, November 20). Bagaimana RCEP bisa menguntungkan dan merugikan Indonesia. Diambil 19 Desember 2020, dari The Conversation website: https://theconversation.com/bagaimana-rcep-bisa-menguntungkan-da n-merugikan-indonesia-150453

Akbar, R. T. (Ed.). (2011). Ekonomi Politik Kemitraan ASEAN: Sebuah Potret 
Kerja Sama (Pertama). Jakarta: Pustaka Pelajar dan Pusat Penelitian Politik LIPI.

Aramaki, K. (2019). Japan's long stagnation, deflation, and abenomics: Mechanisms and lessons. In Japan's Long Stagnation, Deflation, and Abenomics: Mechanisms and Lessons. https://doi.org/10.1007/978-981-13-2176-4

Art, R. J., \& Jervis, R. (2017). International Politics. In Pearson Education (Third). New York: Pearson Education.

Banyu Perwita, D. A. A., \& Yani, D. Y. M. (2014). Pengantar Ilmu Hubungan Internasional (4th ed.). Bandung: PT Remaja Rosdakarya.

Business Insider, \& Martin, W. (2017). These will be the most powerful economies in the world by 2050. Diambil 14 Oktober 2020, dari World Economic Forum website:

https://www.weforum.org/agenda/2017/12/these-will-be-the-most-po werful-economies-in-the-world-by-2050

Ditjen Perundingan Perdagangan Internasional, K. P. R. I., \& ASEAN, D. P. (2019). Selayang Pandang RCEP. Kementerian Perdagangan, hal. 1-8. Diambil dari

https://www.kemendag.go.id/storage/article_uploads/Fb8jI1oDSmNH WU6zHOprsz8M3VwZ7wbVEacCaH6x.pdf

Djegadut, R. (2020, Juli 15). Di Balik Keakraban Menko Luhut dengan Menteri Ekonomi Jepang Kajiyama Hiroshi. Diambil 19 Desember 2020, dari indonews.id website: https://indonews.id/mobile/artikel/31068/Di-Balik-Keakraban-Menko -Luhut-dengan-Menteri-Ekonomi-Jepang-Kajiyama-Hiroshi/

Dourille-Feer, E. (2015). Can the magic of Abenomics suceed? (No. 24). Paris. Dunne, T., Kurki, M., \& Smith, S. (Ed.). (2010). International Relations Theory: Discipline and Diversity (Second). Oxford: Oxford University Press.

Fischetti, A. A., \& Roth, A. (2019). Japan's Belt \& Road Ambivalence - Tokyo Review. Diambil 16 Oktober 2020, dari Tokyo Review website: https://www.tokyoreview.net/2019/05/sino-japanese-review-japans-bri -ambivalence/ 
Gakuto, T. (2020, November 15). RCEP to remove tariffs on 86\% of Japan's exports to China - Nikkei Asia. Diambil 19 Desember 2020, dari Nikkei Asia website: https://asia.nikkei.com/Politics/International-relations / RCEP-to-remo ve-tariffs-on-86-of-Japan-s-exports-to-China

Kan, K. (2020, Desember 18). Japan-South Korea: The Limits of Outreach Without Trust. Diambil 19 Desember 2020, dari The Diplomat website: https:/ / thediplomat.com/2020/12/japan-south-korea-the-limits-of-out reach-without-trust/

Kawashima, S. (2020, Agustus 3). Japan's Painful Choice on RCEP - . Diambil 18 Desember 2020, dari The Diplomat website: https:/ / thediplomat.com/2020/08/japans-painful-choice-on-rcep/

Koga, K. (2016). The rise of China and Japan's balancing strategy: critical junctures and policy shifts in the 2010s. Journal of Contemporary China, 25(101), 777-791. https://doi.org/10.1080/10670564.2016.1160520

Nagata, K. (2020, September 17). What will "Suganomics" look like? . Diambil 19 Desember 2020, dari The Japan Times website: https://www.japantimes.co.jp/news / 2020/09/17/business / economy-b usiness/suganomics-prime-minister/

Noor Hidayat, A. A. (2020). Kereta Cepat Dilanjutkan ke Surabaya, Pemerintah Gandeng Jepang. Diambil 19 Desember 2020, dari Tempo.co website: https:/ / bisnis.tempo.co/read/1347551/kereta-cepat-dilanjutkan-ke-su rabaya-pemerintah-gandeng-jepang

Pekkanen, S. M., \& Tsai, K. S. (2005). Japan and China in the world political economy. Japan and China in the World Political Economy, hal. 1-245. https: / / doi.org/10.4324/9780203099421

Ratnasari, F. E. (2020, September 23). Masa Depan Hubungan Jepang-Indonesia di Tangan PM Suga. Diambil 19 Desember 2020, dari Matamata Politik: Berita Politik Dunia website: https://www.matamatapolitik.com/masa-depan-hubungan-jepang-indo nesia-di-tangan-pm-suga-analisis /

Reily, M. (2018, November 15). Ada Kepentingan Jepang, Kesepakatan Kerja 
Sama Ekonomi RCEP Tertunda. Diambil 19 Desember 2020, dari Katadata.co.id website: https://katadata.co.id/ekarina/berita/5e9a5598010b3/ada-kepentinga n-jepang-kesepakatan-kerja-sama-ekonomi-rcep-tertunda

Rezkisari, I. (2020, Oktober 17). Indonesia Sambut Kedatangan PM Jepang Yoshihide Suga. Diambil 19 Desember 2020, dari Republika Online website:

https://republika.co.id/berita/qibilo328/indonesia-sambut-kedatangan -pm-jepang-yoshihide-suga

sari, S., \& Yani, Y. M. (2017). REVITALISASI HUBUNGAN AMERIKA SERIKAT DI ASIA. Dinamika Global, 4-17.

Setiawan, A., \& Sulastri, E. (2017). Pengantar Studi Politik Luar Negeri. Yogyakarta: UMJ Press.

Suoneto, N., \& Riani, B. (2020, September 22). The outlook of Indonesia-Japan relations under PM Suga. Diambil 18 Desember 2020, dari The Jakarta Post website: https://www.thejakartapost.com/academia/2020/09/22/the-outlook-o f-indonesia-japan-relations-under-pm-suga.html

Tan, H. (2020, September 17). Japan turns to "Suganomics" - but analysts say the policy will likely continue Abe's legacy. Diambil 19 Desember 2020, dari CNBC website: https://www.cnbc.com/2020/09/18/japan-turns-to-suganomics-but-a nalysts-say-the-policy-will-likely-continue-abes-legacy-html

Tani, S., \& Gakuto, T. (2020, September 29). Japan and Australia wary of China as RCEP talks enter last stretch. Diambil 19 Desember 2020, dari Nikkei Asia website:

https://asia.nikkei.com/Spotlight/Asia-Insight/Japan-and-Australia-w ary-of-China-as-RCEP-talks-enter-last-stretch

Tay, S. (2013). Abenomics, Asia \& ASEAN. Japan Spotlight, 13-16.

The Government of Japan. (2017). Abenomics.

Triantama, F. (2020). Interdependensi Ekonomi Sebagai Pencipta Perdamaian Asia Timur. Jurnal Dinamika Global, 5 (02), 278-298. https://doi.org/10.36859/jdg.v5i02.195 
Wakatabe, M. (2015). Japan's Great Stagnation and Abenomics: Lessons for the World. Japan's Great Stagnation and Abenomics: Lessons for the World, hal. 1-209. https://doi.org/10.1057/9781137438850

Wibowo, I. (2020, Januari 27). Indonesia-Jepang Sepakat Selesaikan Protokol Amandemen GR-IJEPA. Diambil 19 Desember 2020, dari Medcom.id website: https://www.medcom.id/ekonomi/mikro/4KZ6D6gK-indonesia-jepangsepakat-selesaikan-protokol-amandemen-gr-ijepa

Yap, J. T. (2013). The Impact of "Abenomics" on Emerging Markets in East Asia. Japan Spotlight, 25-27.

Yoshino, N., \& Taghizadeh-Hesary, F. (2014). Three Arrows of "Abenomics" and the Structural Reform of Japan: Inflation Targeting Policy of the Central Bank, Fiscal Consolidation, and Growth Strategy (No. 492). Tokyo. 